\title{
Development of International Cooperation of the Russian Federation in the Sphere of the Edition and Implementation of Acts of Amnesty
}

\author{
Kohman Dmitry Vadimovich \\ Department of Penitentiary and Criminal Law \\ Voronezh Institute of the Federal Penitentiary Service of \\ Russia \\ Voronezh, Russian Federation \\ Panarin Dmitry Alexandrovich \\ Pskov Branch Academy of the Federal Penitentiary Service \\ of Russia \\ Pskov, Russian Federation
}

\author{
Kemova Natalia Nikolaevna \\ Department duty service and service weapons, \\ the Academy of the Federal Penal Service of Russia \\ Ryazan, Russian Federation \\ natalyakoluntaeva@mail.ru \\ Kazak Bronislav Bronislavovich \\ Department of Human Rights, Law Enforcement, criminal \\ law and process \\ Pskov State University \\ Pskov, Russian Federation \\ kafoppd@rambler.ru
}

\author{
Abramova Natalya Gennadyevna \\ Department of criminal law disciplines \\ Pskov, Russian Federation \\ kafoppd@rambler.ru
}

\begin{abstract}
In article problematic issues of international cooperation in the sphere of the edition and implementation of acts of amnesty are investigated, it is noted that amnesty is an act not only legal, but also socio-political which entirely depends on will and the interests of authorities in power.
\end{abstract}

Keywords: international cooperation, integration, economic security, amnesty, the political legal act, early release from serving sentence

\section{INTRODUCTION}

On September 7, 2013, Xi Jinping, President of the PRC, d Current trends in the global integration show the inevitable problems connected with transnational corruption, illegal migration, ethnic crime, smuggling, shadow economy, etc. The world community recognizes these problems and allies against crime, tries to comply with the accepted legal principles, including the inevitability of punishment and criminal prosecution. At the same time, no attention is paid to unified policy and ensuring cooperation in the field of exemption from criminal liability and punishment. The stated thesis is especially relevant for amnesty that is a type of exemption from criminal liability and punishment applicable to entire groups of people. The large-scale amnestyy in a state may negatively affect the criminal situation of the whole region.

However, this situation is not surprising, since amnesty by its legal nature is a one-time phenomenon that is used with different frequency depending on the demand. According to A. A. Malinovskiy, the science of comparative law cannot solve the tasks of a detailed theoretical analysis and develop recommendations for improving all the institutions of criminal law. Such work should be a part of separate studies [1]. Our aim is to determine the prospects for collaboration between the Russian Federation and other countries on the issuing and implementing of amnesty acts, identifying the subjects of such collaboration, its forms and directions.

In this regard, V.P. Revin speaks of modern international cooperation as a multi-level interaction, carried out by the world community, the states of the European Union, the Commonwealth of Independent States (hereinafter - the CIS), the Eurasian Economic Union (hereinafter - the EAEU), when international formations, based on the production cooperation, the development of resources or services, are created. [2]. 


\section{MethodS}

According to their relationship to the institution of amnesty, all countries of the world community can be classified into three groups: 1) countries that do not have norms of amnesty in their legal system; 2) countries that have amnesty norms, but have a negative attitude to this institution and (or) they are used extremely rarely 3 ) countries that issue acts of amnesty at certain intervals.

The last group includes the Russian Federation and other countries of the former Soviet Union. These states not only continue to issue amnesty acts, but sometimes they do it at about the same time. Thus, in 2013 many post-Soviet countries announced amnesties, including Georgia, Kazakhstan, Kyrgyzstan, Russia, Turkmenistan, Uzbekistan, and Ukraine. The total number of convicts, included in the amnesty, exceeded 110 thousand.

Meanwhile, cooperation on issuing and implementing amnesty acts seems possible only between the EAEU states, because they have formed a common economic space, their relations continue to develop, they all have preserved the institution of amnesty in their legal systems and they use it. For example, since the Soviet Union breakup, amnesty was declared 9 times in Kazakhstan, 14 times - in Belarus, 19 times - in Russia.

Some foreign countries, mainly countries of the AngloSaxon legal system, have a negative attitude to this legal phenomenon or have no amnesty standards in their legislation. Due to the above-mentioned fact and complicated international relations of the Russian Federation with a number of states, the interaction on issuing and implementing amnesty acts seems impossible beyond the framework of the EAEU.

\section{RESULTS}

We interviewed 107 criminal law experts (university professors, judges, crime investigators and public prosecution officers): the majority (64.3\%) consider cooperation on issuing and implementing amnesty acts within the EAEU possible and desirable, the CIS takes the second place $(31.5 \%)$, and the Council of Europe is in the third place $(4.2 \%)$

To specify the problem, O. M. Ivanova draws attention to a significant number of normative legal acts that unite states for fight against cross-border crimes. Conventions, regional and bilateral agreements can be distinguished among them. Usually the priority is given to bilateral agreements. Agreements on the legal support in criminal matters, on the extradition of criminals, on the transfer of convicts to the state of their citizenship and to the place of the further serving of sentences are widespread. To coordinate cooperation, interdepartmental agreements are being made. The regional level of cooperation is the association of states from a certain geographical region (Council of Europe, Organization of American States, League of Arab States, African Union). These organizations, as well as their constituent states, are interested in the security of the region, that is why many conventions are signed within their framework [3].
Based on the foregoing, it will be appropriate that the EAEU arrangements on the application of the amnesty institution will be given a form of a separate agreement. The validity of a separate agreement in this sphere is recognized by $81.1 \%$ of the interviewed specialists.

The main areas of cooperation in this sphere are the following: the development of a unified amnesty policy; unification of amnesty legislation; elimination of legislative gaps in the amnesty acts.

\section{DISCUSSION}

To establish a unified amnesty policy, it is necessary to accept common terminology for all countries. However, first of all, state agents should agree that, when choosing categories of convicts, included in the amnesty, it is necessary to pay attention to those categories that have the least danger to the public, to take into account the nature and degree of the public danger of their crimes, as well as to estimate abilities of employment and accommodation for the amnesty people after being released from serving a sentence. As the experience of the EAEU countries shows, the above mentioned conditions cannot always be achieved. Thus, in the Republic of Armenia after the amnesty dedicated to the 100th anniversary of the First Armenian Republic and the 2800th anniversary of Yerevan, there has been an increase in crime mostly there were lucrative crimes.

The procedure of unifying the amnesty legislation of the EAEU countries should be based on the identification of common and unique norms. The first significant difference takes place already at the stage of the amnesty act adoption. According to the constitutions of the EAEU states, their legislative branches of power fulfill the amnesty act adoption. In the Republics of Armenia, Belarus, Kazakhstan, and Kyrgyzstan, amnesty has the form of a law and is adopted by the parliament, and in the Russian Federation amnesty is adopted by the State Duma of the Federal Assembly $\square$ the lower house of parliament, and has the form of a decree. Significant differences are also the following: in Armenia the amnesty is possible only at the suggestion of the President, in Belarus the draft act on amnesty is developed by the Department of the Interior, and in Kyrgyzstan there is a separate Law "On the Basic Principles of Amnesty and the Procedure for its Application".

An example of the legislative gaps in the implementation of amnesty acts by the EAEU countries is the lack of regulation of cases when a person is included in two amnesty acts issued in different states at once. Such a thing could have happened when a person was taken from the country where he was convicted, to another country where he is a citizen or permanently resides in its territory, for further serving his sentence. As a result, the person actually acquires the right to take two amnesties of different states at once $\square$ the Law of the Republic of Belarus dated June 17, 2014 No. 163-Z "On Amnesty Dedicated to the 70th Anniversary of Belarus Emancipation from Nazi Invaders" and the Decree of the State Duma of the Russian Federation dated April 24, 2015 No. 6576-6 of the State Duma "On Declaring Amnesty Dedicated to the 70th anniversary of Victory in the Great Patriotic War 
committed an intentional crime. The proposed principle in the international criminal law was supported by $74.5 \%$ of the interviewed specialists.

Thus, there is a reasonable necessity for legal support of cooperation among the EAEU states in the process of issuing and implementing of amnesty acts. The legal basis for such cooperation could be the model legislation (The Framework of the Criminal Legislation of the CIS Countries, The Model Penal Code for the CIS Countries). However, it is advisory in nature and does not have legal force. In this regard, we propose to ensure cooperation in this area by a separate agreement between the parties (the Russian Federation, the Republic of Belarus, the Republic of Kazakhstan, the Republic of Armenia and the Kyrgyz Republic) on the basis of the Treaty on the Forming of The Common Customs Territory and the Customs Union, dated October 6, 2007, as well as of the general principles of the international law with its obligatory ratification. The agreement should be open for ratification by any state that wishes to become a member of the Customs Union.

\section{REFERENCES}

[1] A. A. Malinovskiy, "Criminal Law of the Foreign Countries", M.: Noviy Jurist, 1998, 128 p.

[2] V. P. Revin, "The International Cooperation in the Fight against Crime within the Framework of the Criminal Policy of the Russian Federation (assessment and optimization problems)", International Cooperation of the Eurasian States: politics, economics, law, 2015, no. 1, 40 p.

[3] O. M. Ivanova, "About the International Cooperation in the Fight against Crime", Vector Nauki TSU, 2016, no. 3, 41 p.

[4] S. P. Scherba, P. A. Smirnov, and E. J. Chetvertakova, "The Principle "non bis in idem" in the International Cooperation on the Criminal Cases", Reporter of the Academy of General Procuracy of the Russian Federation, 2017, no. 1, pp. 142-148. free pardon or amnesty for a person if he/she was previously exempted from criminal liability and punishment and again 